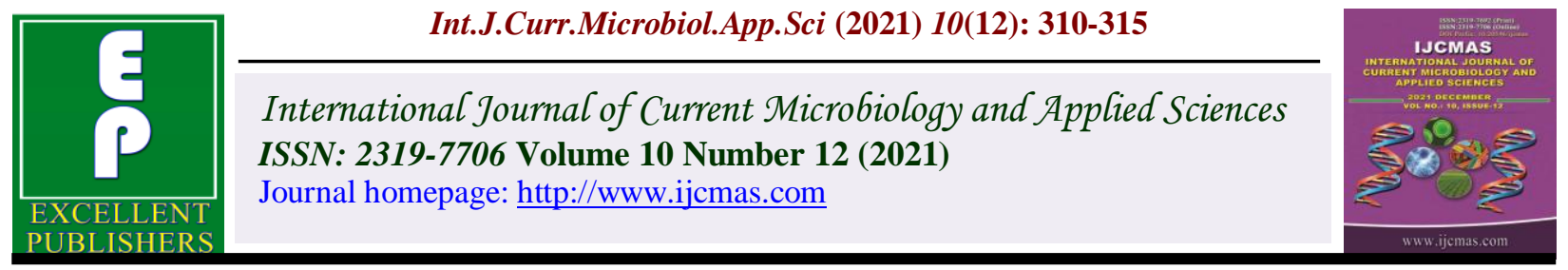

\title{
Genetic Diversity of Chickpea Pod Borer, Helicoverpa armigera (Hubner)
}

\author{
G. Sai Karthik ${ }^{1 *}$ and A. S. Vastrad ${ }^{2}$ \\ ${ }^{1}$ Department of Agricultural Entomology, College of Agriculture, Vijayapura, University of \\ Agricultural Sciences, Dharwad-580005, Karnataka, India \\ ${ }^{2}$ University of Agricultural Sciences, Dharwad- 580005, Karnataka, India \\ *Corresponding author
}

A B S T R A C T

Keywords

Helicoverpa, polyphagous, RAPD, genetic, diversity, chickpea

Article Info

Received: 02 November 2021 Accepted:

30 November 2021

Available Online:

10 December 2021
Helicoverpa armigera (Hübner) is a polyphagous and cosmopolitan pest inflicting annual crop losses worth US \$ 1 billion. Here, we aimed at studying the genetic diversity of pod borer using random primers. Thirteen random primers generated a total of total of 150 amplicons with an average of 11.53 bands per primer. There were a total of 138 polymorphic bands (average of 10.61 bands per primer) with polymorphism ranging from 66.6 to $100 \%$. The similarity coefficient values ranged from 0.13 to 0.42 . UPGMA based dendrogram revealed the presence of two principal clusters which were further subdivided into 12 sub-clusters. The most striking inference of our study was that larval populations collected in the presence of multiple hosts were hyper diverse forming a separate cluster clearly distinct from populations collected on sole chickpea.

\section{Introduction}

Helicoverpa armigera (Hübner) (Noctuideae: Lepidoptera) is a serious pest responsible for US $\$ 1$ billion annual crop losses in India alone (Chandrashekar and Gujar, 2004). In India the pest is known to thrive on 182 species of host plants belonging to 47 families (Pawar, 1998). Differences in ecological behaviour of the pest are known to exist in populations collected from diverse hosts and geographic locations. Presence of strong genetic variability in the pest governing its behaviour makes it a serious pest on several crops (Scott et al., 2005). Studies on genetic diversity of the pest provides a better insight in understanding the structure, behaviour and population dynamics of the pest, its response to selection pressure and management strategies.

Among the wide range of DNA marker techniques available for genetic analysis, RAPD-PCR is a simple approach to unravel the genetic structure of the organisms. It is 
cheaper, rapid, non-radioactive, requiring only a small amount of DNA and does not require any prior knowledge of DNA sequence (Moorthy et al., 2013). The added advantage of RAPD method is its ability to generate polymorphisms and genome analysis of any organism employing a universal set of primers (Jain et al., 2010). In view of above aspects the present study was initiated to assess RAPD-based genetic diversity of $H$. armigera collected from chickpea.

\section{Materials and Methods}

The present study was conducted during rabi summer, 2017-18 at the College of Agriculture, Vijayapura (sample collection) and Microbial Genetics Laboratory, Department of Agricultural Microbiology, College of Agriculture, Dharwad. Helicoverpa larvae were collected weekly from experimental fields of chickpea, College of Agriculture, Vijayapura. Collections were continued for six weeks and larvae were preserved in $70 \%$ ethyl alcohol at $-20{ }^{\circ} \mathrm{C}$ for further analysis. Genomic DNA of the field collected larvae was isolated using CTAB (Cetyl Trimethyl Ammonium Bromide) method with slight modifications (Subramanian and Mohankumar, 2006). The quantification of genomic DNA was done using Nano Drop ND-1000 spectrophotometer and visualised on $0.8 \%$ agarose with $1 \mathrm{ml}$ of $0.5 \mathrm{X}$ TAE buffer and $5 \mu \mathrm{l}$ of ethidium bromide and compared with a reference of 50 bp DNA ladder (and $1 \mathrm{~kb}$ ladder wherever necessary). OD260/280 was employed to assess the purity of DNA. A ratio less than 1.7 indicates protein contamination, whereas ratio greater than 1.8 indicates RNA contamination.

Thirteen primers (Table 1) were considered based on the band pattern repeatability. The PCR mixture consisted of $2 \mu$ l of template DNA, $0.3 \mu \mathrm{l}$ Taq polymerase, $1 \mu \mathrm{l}$ of Taq buffer, $1 \mu \mathrm{l}$ of dNTPs and $5.7 \mu \mathrm{l}$ of nuclease free water (M/S Bangalore Genei Pvt. Ltd., Bangalore and Fermentas Company, Bangalore). The PCR amplification was carried out in Eppendorf Master Cycler gradient (Hamburg, Germany and these reaction products were kept at $4{ }^{\circ} \mathrm{C}$ until further use. RAPD-PCR products were then analysed on $2 \%$ agarose with $2 \mathrm{ml}$ of $0.5 \mathrm{X}$ TAE buffer and $10 \mu$ l of ethidium bromide with $50 \mathrm{bp}$ ladder as a reference $(1 \mathrm{~kb}$ ladder wherever necessary). After electrophoresis, the gel was visualised on a UV transilluminator and photographed with gel documentation unit for further analysis. Amplification profiles for all the primers were observed carefully and the individual bands were scored as 1 or 0 based on presence or absence of bands with reference to the DNA ladder generating the 0,1 matrices. The scored data matrix was subjected to analysis using the standard procedure in DARwin 6.0 CIRAD package. A dendrogram was constructed after the cluster analysis of similarity coefficients by using pair-group method (UPGMA) analysis using in DARwin 6.0 CIRAD.

\section{Results and Discussion}

A total of 150 amplicon levels (average of 11.53 bands per primer) with 138 polymorphic bands (average of 10.61 bands per primer) were generated with polymorphism ranging from 66.6 to $100 \%$ (Table 1). The amplicon size ranged from $100 \mathrm{bp}$ to more than $1000 \mathrm{bp}$.

The gel electrophoresis profile of $H$. armigera larvae using OPB-13 and OPAT-3 primers is shown in Fig. 1. Even a small sample size of $H$. armigera collected at different time intervals in the present study provided a great insight into the variations in the population. Earlier studies (Rahman et al., 2014; Yenagi et al., 2012) documenting high degree of polymorphisms generated by RAPD markers involved extensive sampling from different host plants and geographical locations. 
The highest number of amplicons were produced by OPF-3 primer (19 amplicons) followed by OPB-13 (18 amplicons). The lowest numbers of amplicon levels are produced by OPA-15 primer ( 3 amplicons). The data matrix prepared by visual observation for presence (1) or absence (0) of bands for each primer was used to construct genetic similarity distance table (DARwin 6.0 CIRAD-similarity coefficient). The similarity coefficient values ranged from 0.13 (between tenth and eleventh samples) to 0.42 (first and fourteenth sample) (Table 2).

The RAPD polymorphisms were analysed with the help of similarity coefficient values from which an Unweighted Paired Group Method with Arithmetic Mean (UPGMA) based dendrogram was constructed. The dendrogram (Fig. 2) revealed the presence of two principal clusters $\mathrm{X}$ and $\mathrm{Y}$ where the cluster $\mathrm{Y}$ is composed of only two samples (1 and 3) which belong to the first week collection. The principal cluster $\mathrm{X}$ is further divided into two clusters i.e., $X_{1}$ and $X_{2}$ at similarity coefficient of 0.015 . Cluster $\mathrm{X}_{1}$ includes seven samples (sample no. 2, 4, 5, 6, $7,8,9)$ which belong to third and fourth week collection except second sample which belongs to first week. Cluster $\mathrm{X}_{2}$ included all the remaining seven samples $(10,11$-week 4 ; 12, 13-week 5; 14, 15, 15- week 6).

Table.1 Detailed summary of RAPD-PCR analysis

\begin{tabular}{|c|c|c|c|c|c|c|}
\hline $\begin{array}{c}\text { Sl. } \\
\text { No. }\end{array}$ & $\begin{array}{c}\text { OP } \\
\text { series }\end{array}$ & $\begin{array}{c}\text { Primer sequence } \\
\left(\mathbf{5}^{\prime} \rightarrow \mathbf{3}^{\prime}\right)\end{array}$ & $\begin{array}{c}\text { Total no. of } \\
\text { amplified } \\
\text { bands }\end{array}$ & $\begin{array}{c}\text { Total no. of } \\
\text { polymorphic } \\
\text { bands }\end{array}$ & $\begin{array}{c}\text { Per cent } \\
\text { polymorphism }\end{array}$ & $\mathbf{T}_{\mathbf{m}}$ \\
\hline 1. & A-15 & TTCCGAACCC & 3 & 3 & 100 & $35^{\circ} \mathrm{C}$ \\
\hline 2. & A-16 & AGCCAGCGAA & 12 & 9 & 75 & $37^{\circ} \mathrm{C}$ \\
\hline 3. & A-20 & GTTGCGATCC & 11 & 11 & 100 & $38^{\circ} \mathrm{C}$ \\
\hline 4. & B-12 & CCTTGACGCT & 11 & 11 & 100 & $38^{\circ} \mathrm{C}$ \\
\hline 5. & B-13 & TTCGCTCGCT & 18 & 18 & 100 & $35^{\circ} \mathrm{C}$ \\
\hline 6. & C-9 & CTCACCGTCC & 7 & 6 & 85.7 & $36^{\circ} \mathrm{C}$ \\
\hline 7. & F-03 & CCAAGCTTCC & 19 & 19 & 100 & $35.5^{\circ} \mathrm{C}$ \\
\hline 8. & F-04 & GGTGATCAGG & 12 & 11 & 91.6 & $35.5^{\circ} \mathrm{C}$ \\
\hline 9. & K-18 & CCTAGTCGAG & 7 & 6 & 85.7 & $36^{\circ} \mathrm{C}$ \\
\hline 10. & AT-01 & CAGTGGTTCC & 15 & 14 & 93.3 & $36^{\circ} \mathrm{C}$ \\
\hline 11. & AT-03 & GACTGGGAGG & 14 & 14 & 100 & $36^{\circ} \mathrm{C}$ \\
\hline 12. & AT-04 & TTGCCTCGCC & 12 & 8 & 66.6 & $36^{\circ} \mathrm{C}$ \\
\hline 13. & AT-08 & TCCTCGTGGG & 9 & 8 & 88.8 & $36^{\circ} \mathrm{C}$ \\
\hline & Total & & 150 & 138 & 1186.7 & \\
\hline & Average & & 11.53 & 10.61 & 91.28 & \\
\hline
\end{tabular}


Table.2 Similarity distance matrix table for collected samples of Helicoverpa armigera larvae

\begin{tabular}{|c|c|c|c|c|c|c|c|c|c|c|c|c|c|c|c|c|}
\hline Week & Sample no. & 1 & 2 & 3 & 4 & 5 & 6 & 7 & 8 & 9 & 10 & 11 & 12 & 13 & 14 & 15 \\
\hline \multirow[t]{3}{*}{1} & 1 & 0 & & & & & & & & & & & & & & \\
\hline & 2 & 0.35 & & & & & & & & & & & & & & \\
\hline & 3 & 0.29 & 0.32 & & & & & & & & & & & & & \\
\hline \multirow[t]{3}{*}{2} & 4 & 0.32 & 0.21 & 0.28 & & & & & & & & & & & & \\
\hline & 5 & 0.37 & 0.31 & 0.34 & 0.27 & & & & & & & & & & & \\
\hline & 6 & 0.36 & 0.30 & 0.32 & 0.26 & 0.25 & & & & & & & & & & \\
\hline \multirow[t]{3}{*}{3} & 7 & 0.35 & 0.30 & 0.31 & 0.26 & 0.32 & 0.30 & & & & & & & & & \\
\hline & 8 & 0.38 & 0.32 & 0.34 & 0.28 & 0.30 & 0.28 & 0.32 & & & & & & & & \\
\hline & 9 & 0.35 & 0.29 & 0.32 & 0.26 & 0.27 & 0.26 & 0.30 & 0.24 & & & & & & & \\
\hline \multirow[t]{2}{*}{4} & 10 & 0.33 & 0.27 & 0.30 & 0.24 & 0.25 & 0.24 & 0.28 & 0.25 & 0.22 & & & & & & \\
\hline & 11 & 0.33 & 0.27 & 0.30 & 0.24 & 0.25 & 0.24 & 0.28 & 0.25 & 0.22 & 0.13 & & & & & \\
\hline \multirow[t]{2}{*}{5} & 12 & 0.38 & 0.32 & 0.35 & 0.28 & 0.30 & 0.29 & 0.33 & 0.29 & 0.27 & 0.20 & 0.20 & & & & \\
\hline & 13 & 0.41 & 0.34 & 0.37 & 0.31 & 0.32 & 0.31 & 0.35 & 0.32 & 0.29 & 0.23 & 0.23 & 0.26 & & & \\
\hline \multirow[t]{3}{*}{6} & 14 & 0.42 & 0.36 & 0.38 & 0.32 & 0.34 & 0.32 & 0.36 & 0.33 & 0.30 & 0.24 & 0.24 & 0.26 & 0.30 & & \\
\hline & 15 & 0.41 & 0.35 & 0.38 & 0.31 & 0.33 & 0.32 & 0.36 & 0.32 & 0.30 & 0.24 & 0.24 & 0.25 & 0.29 & 0.25 & \\
\hline & 16 & 0.36 & 0.30 & 0.33 & 0.27 & 0.28 & 0.27 & 0.31 & 0.28 & 0.25 & 0.19 & 0.19 & 0.22 & 0.23 & 0.25 & 0.25 \\
\hline
\end{tabular}

Fig.1 Gel electrophoresis profile of collected samples of Helicoverpa armigera larvae using OPB-13 and OPAT-3 primers. Sample 1, 2 and 3: Week 1; Sample 4, 5, 6: Week 2; Sample 7, 8, 9: Week 3; Sample 10, 11: Week 4; Sample 12, 13: Week 5; Sample 14, 15, 16: Week 6; L and $\mathrm{L}_{1}: 50$ bp ladder; $\mathrm{L}_{2}$ : $1 \mathrm{~kb}$ ladder, DD: Double digest

OPB-13

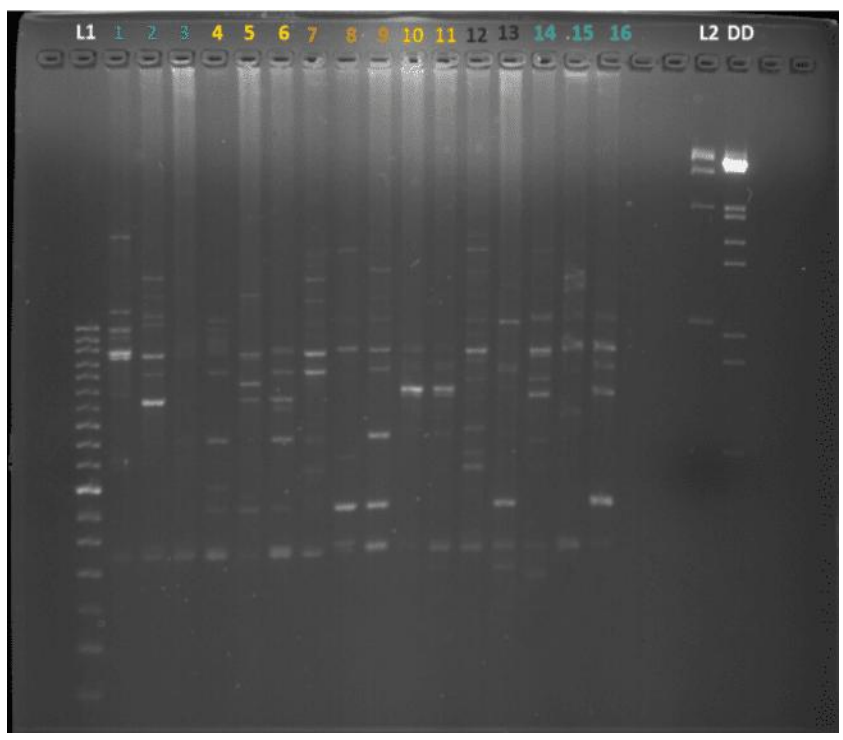

OPAT-3

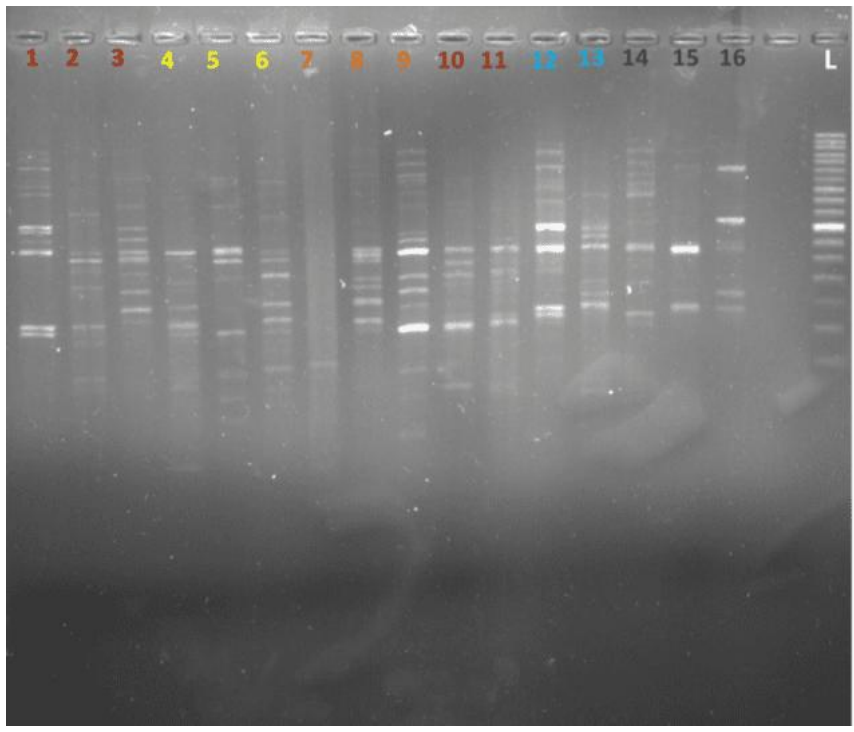


Fig.2 Dendrogram showing genetic relatedness of Helicoverpa armigera collected at different time intervals. Sample 1, 2, 3: Week 1; Sample 4, 5, 6: Week 2; Sample 7, 8, 9: Week 3; Sample 10, 11: Week 4; Sample 12, 13: Week 5; Sample 14, 15, 16: Week 6

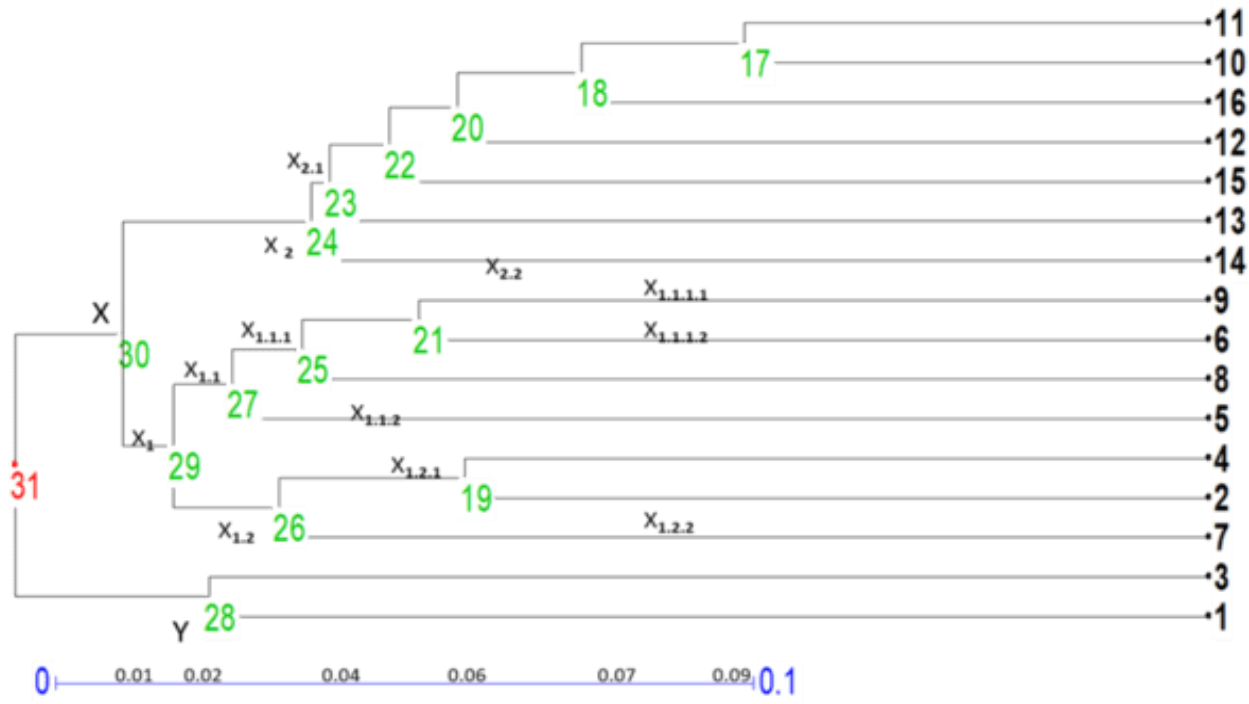

DARw in 6.0 CCRAD - 14/06/2018 - Simlarity Coefficient

Closer genetic structure in $\mathrm{Y}$ and $\mathrm{X}_{1}$ separated from $\mathrm{X}_{2}$ was due to the fact that populations in cluster $\mathrm{Y}$ and $\mathrm{X}_{1}$ were sampled during the first three weeks where alternate hosts like pigeon pea, cotton etc. were available in the vicinity. It is possible that the pod borer being highly polyphagous might have migrated from hosts other than chickpea (pigeon pea or cotton) where they fed on them resulting in genetic structure of cluster $\mathrm{X}_{1}$ and $\mathrm{Y}$ being different from that of $\mathrm{X}_{2}$.

The hypothesis is that as the pest doesn't undergo any diapause, it will be continuously searching for a suitable host for its survival. This phenomenon is supported by the fact that the pest is well known for its long distance high migratory potential (Farrow, 1994; Pedgley, 1985). It has been reported that this pest can travel more than $2000 \mathrm{~km}$ (Nibouche et al., 1998).

Lesser genetic variation in $\mathrm{X}_{2}$ (in contrary to greater variation in populations of $\mathrm{X}_{1}$ and $\mathrm{Y}$ ) might be due to feeding on sole chickpea and also due to interbreeding among the populations of the $\mathrm{X}_{2}$ and $\mathrm{Y}$ that caused the gene flow reducing the variability between them. The present results are in line with previous studies reporting the influence of host plants on the variability of pod borer (Subramanian and Mohankumar, 2004; Firempong and Zalucki, 1990). The greatest variation observed between the samples of $H$. armigera (1 and 14) can be explained by the possibility of migration from different geographic locations or from different host plants and also by different sampling periods. The present study also confirms the earlier reports (Scott et al., 2005) on genetic shifts in $H$. armigera over monthly intervals.

Studying the genetic structure of Helicoverpa helps us in developing better management strategies to control the pest as high genetic variability results in faster development of resistance to insecticides, greater speciation as pest population varies in their susceptibility to various insecticides. 


\section{Acknowledgements}

I would like to express my sincere gratitude to Arun. Y. P, Post graduate student, Department of Agricultural Biotechnology, UAS, Dharwad for his utmost help during my research.

\section{References}

Chandrashekar, K., and Gujar G. T., 2004. Development and mechanisms of resistance to Bacillus thuringiensis endotoxin Cry lAc in the American bollworm Helicoverpa armigera (Hubner). Indian Journal of Experimental Biology. 42: 164-173.

Farrow, R. A., 1984. Detection of transoceanic migration of insects to a remote island in Coral Sea, Willis island, Australian Journal of Ecology. 9: 253-272.

Firempong, S and Zalucki M. P., 1990. Host plant selection by Helicoverpa armigera (Hubner) (Lepidoptera: Noctuidae): Role of certain plant attributes, Australian Journal of Zoology. 37: 675-883.

Jain, S. K., Neekhra. B, Pandey. D and Jain, K., 2010. RAPD marker system in insect study: A review. Indian Journal of Biotechnology. 9: 7-12.

Moorthy, S. M., Chandrakanth, N., Ashwath, S. K., Kumar, V. and Bindroo, B. B., 2013. Genetic diversity analysis using RAPD marker in some silkworm breeds of Bombyx mori L, Annals of Biological Research. 4: 82-88.

Nibouche, S., Toubon, J. F. and Serge, P., 1998. Allozyme polymorphism in the cotton bollworm Helicoverpa armigera (Lepidoptera: Noctuidae): comparison of African and European populations. Heredity. 80: 438-445.

Pawar, V. M., 1998. Microbial control of Helicoverpa spp on pulse crops. Aditya books private limited, New Delhi, India. 55-78.

Pedgley, D. E., 1985. Windborne migration of Heliothis armigera (Hubner) (Lepidoptera: Noctuidae) to the British Isles, Entomology Gazzette. 36: 15-20.

Rahman, A. Z., Haque, M. A., Alam, S. N. and Balasubramani, V.. 2014. Genetic diversity of fruit borer, Helicoverpa armigera (Lepidoptera: Noctuidae) based on Random amplified polymorphic DNA- Polymerase Chain Reaction. Bangladesh Journal of Agricultural Research. 39: 263-271.

Scott, K. D., Wilkinson, K. S., Larence, N., Lange, C. L., Scott, L. J., Merritt, M. A., Lowe, A. J. and Graham, C. G., 2005. Gene-flow between populations of cotton bollworm Helicoverpa armigera (Lepidoptera: Noctuidae) is highly variable between years. Bulletin of Entomological Research. 95: 381392.

Subramanian, S and Mohankumar, S., 2006. Genetic variability of the bollworm, Helicoverpa armigera, occurring on different host plants. Journal of Insect Science. 6: 26.

Yenagi, B. S., Patil, V. C., Biradar, D. P. and Khadi, B. M., 2012. Molecular diversity of cotton bollworm, Helicoverpa armigera (Hubner) using RAPD markers, Middle-East Journal of Scientific Research. 11: 61-65.

\section{How to cite this article:}

Sai Karthik, G. and Vastrad, A. S. 2021. Genetic Diversity of Chickpea Pod Borer, Helicoverpa armigera (Hubner). Int.J.Curr.Microbiol.App.Sci. 10(12): 310-315. doi: https://doi.org/10.20546/ijcmas.2021.1012.036 